motion of science and the diffusion and extension of useful knowledge. Among its resident professors have been Davy and Faraday, and its present director is Professor George Porter. The current functions of the Royal Institution, as Professor Porter explained last week to the clinking of champagne glasses, are to serve as a society for the advancement of scicnce, as a national archive for the history of science, as a theatre for scientific lectures and meetings and as a research laboratory. The enviable success of the institution's appeal will no doubt help.

\section{Computer Control}

In the future, British industry will apply computers to production and stock control to the same extent as they are now used in accountancy. This was the theme of a symposium organized by the British Computer Society in London, on March 20. More than 1,000 delegates heard from British and American experts how computers can be applied to the scheduling of production on the shop floor, to the control of materials needed in the manufacturing processes and to the efficient stocking of the finished product.

There still seems to be a variety of pitfalls in the introduction of computers into production controlnot the least the problems associated with people. One of the speakers pointed out that two of the commonest mistakes made by management are the failure to take into account the limits of comprehension of employees and the neglect of those parts of the control system which are placed outside the computer. This means that more attention needs to be paid to gathering data for the computer, and to the way in which the computer output is used by management and personnel on the shop floor. And, not unnaturally, there is always the lurking fear that people are being replaced by machines.

Several delegates to the symposium seemed doubtful whether computer production and stock control systems had reached the stage of making themselves pay. There seems to be no clear-cut answer to this - obviously it is difficult to estimate the financial saving made by benefits such as less capital tied down in stock and work-in-progress, better delivery dates and so on which are claimed by advocates of computer systems. Nevertheless, more and more manufacturers are turning to computer systems, especially in the United States, which is clearly showing the way in this field.

One of the questions which the symposium tried to answer was whether the smaller firm should go in for production control by computer when big organizations are obviously running into difficulties in this field. Mr B. G. Roberts, computer development manager for Belling and Lee Ltd, defined the smaller firm as one with less than $£ 60,000$ per annum to spend on data processing during the first few years of operating a computer. $\mathrm{He}$ made the point that although the amount of data to be dealt with is less than in a larger company, the number of processes through which the data has to go may be just as great. Because the data handling procedures rather than the bulk of data provide many of the problems, and because big organizations have the resources to handle large amounts of data, it seems that small firms are less likely to be successful in introducing a computer than large ones.
Nevertheless, the chairman of the symposium, $\mathrm{Mr}$ W. G. E. Hulse, who is manager for production planning and material control at Standard Telephones and Cables, said in his summing-up that the emphasis in the future will be on the smaller companies. Because there are common ingredients to the production problems of many companies working in the same field, there is a need for co-operation in setting up computer centres. This poses problems in the security of business information but, as $\mathrm{Mr}$ Hulse pointed out, companies already rely on the confidential nature of bank accounts so why not trust computer centres in the same way?

\section{New Ideas}

THE emphasis was once again on the small firm at a conference with the title "Getting New Ideas off the Ground" held in London on March 21. Arranged by the Institute of Directors in association with the National Research Development Corporation, its aim was to tell senior management about the NRDC and the way it can help industry. The NRDC was set up in 1948 after it was realized how much had been lost by the failure fully to exploit commercially the discovery of radar and penicillin as well as many other discoveries pioneered in Britain. Its aim is to provide support for technological developments of potential commercial importance and to encourage industry to adopt new methods and products invented in government and university laboratories and elsewhere.

Sir Donald Stokes, chief executive and deputy chairman of British Leyland Motor Corporation, said in his opening address that no firm, however large or however small, need have any hesitation in putting its problems to the NRDC for consideration. He admitted that management was still far too stuffy about new ideas and was reluctant to give revolutionary thoughts a trial.

The message of the conference was that small firms should not be reticent in using the NRDC. Clearly large companies are aware of the NRDC and several of them are using its facilities, but the organizers felt that the functions of the NRDC needed emphasizing to the smaller firm.

\section{Data Centre for Oceanographers}

THe Natural Environment Research Council is to set up a British Oceanographic Data Service at the National Institute of Oceanography, Godalming. The head of the unit will not be appointed for another three months or so, but a steering committee of nine members has been announced and it had its first meeting last week. The chairman of the steering committee is Dr G. Deacon, director of the National Institute of Oceanography. As with many other subjects there is an increasing amount of data which needs handling in a systematic way. It is hoped that the centre will use modern methods of data storage-punched tape, a computer, and so on, and that it will have telex links with other oceanographic and research institutions.

This will not be the first oceanographic data centre in the world. There is one at Copenhagen run by the International Council for the Exploration of the Sea, and others in Hamburg and Ottawa, for example. The idea now is to have national data banks co-ordinating 